\title{
Physalis angulata L. propagation in vitro ${ }^{1}$
}

\author{
João Antônio Ramos de Oliveira', Diego Pascoal Golle ${ }^{2}$, André Schoffel ${ }^{3}$, \\ Juliane Nicolodi Camera ${ }^{2}$, Jana Koefender ${ }^{2} *$ (1)
}

$10.1590 / 0034-737 X 201966060010$

\begin{abstract}
Physalis angulata $\mathrm{L}$. is a plant with great fruit production potential, mainly in family farms, due to its versatility and valuable products such as jellies and juice concentrates. The aim of the present study is to evaluate the effect of two cytokines - i.e., plant growth regulators 6- benzylaminopurine (BAP) and kinetin (KIN) -, in association, or not, with auxin (2,4-dichlorophenoxyacetic acid - 2.4-D), on P. angulata multiplication in vitro. The experiment followed a completely randomized design, with eighteen treatments and five repetitions, based on factorial arrangement $2 \times 5 \times 2$. Cytokinin sources were used at concentrations: $0,2.5,5.0,7.5$ and $10 \mathrm{mg} \mathrm{L}^{-1}$; in the presence $\left(0.05 \mathrm{mg} \mathrm{L}^{-1}\right)$ or absence of 2.4-D. Explants comprised nodal segments (approximately $1 \mathrm{~cm}$ ) deriving from Physalis seed germination in vitro. Results indicate that the growth regulator KIN, at $5 \mathrm{mg} \mathrm{L}^{-1}$ concentration and in the absence of auxin 2.4-D, has potential to enable longer shoot length and larger number of internodes. However, the culture medium (MS) without plant growth regulators recorded higher biomass (fresh and dry weight) and increased root rate.
\end{abstract}

Keywords: Physalis; auxins; in-vitro culture.

\section{INTRODUCTION}

Physalis angulata L. (Solanaceae) is an annual plant species widely distributed in the United States, Central and South Americas, as well as in tropical regions worldwide (Soares et al., 2009). Its fruit is acknowledged as a morphological aspect of genus Physalis, which is characterized by a balloon-like calyx that fully expands and wraps the fruit. $P$. angulata has arisen global interest for medicinal, nutritional and pharmaceutical purposes, since it is rich in antioxidants, polyunsaturated fatty acids, vitamins $\mathrm{A}, \mathrm{B}, \mathrm{C}, \mathrm{E}$ and $\mathrm{K} 1$, as well as in essential minerals. (Puente et al., 2011).

Physalis can be multiplied in different ways, including the seminal route. However, the micropropagation technique enables the mass production of genetically uniform seedlings with known sanitary features, a fact that leads to more homogenous, productive and profitable crops (Guo et al., 2014). Thus, this technique enables improving the production of plants with similar features; therefore, it helps homogenizing productivity and improving farmers' income.

The appropriate selection of source explants is one of the key processes used to enable the successful establishment of protocols focused on plant multiplication in vitro. Based on the use of seeds, it is possible obtaining seedlings and, therefore, young contamination-free explants, whereas the use of young nodal segments enables generating a large number of plantlets without callus formation, as well as reducing plants' potential to present somaclonal variation (Koca \& Aasim, 2015). In addition, studies conducted with other species (Physalis peruviana) belonging to the same genus have highlighted the use of seeds and nodal segments as a promising way to obtain explants (Chaves et al., 2005).

\footnotetext{
Submitted on June $05^{\text {th }}, 2019$ and accepted on October $20^{\text {th }}, 2019$.

1 This work is part of the first author's Master Dissertation.

${ }^{2}$ Universidade de Cruz Alta, UNICRUZ, Mestrado Profissional em Desenvolvimento Rural, Cruz Alta, Rio Grande do Sul, Brasil. joantoniramoliv@gmail.com; dgolle@unicruz.edu.br; jcamera@unicruz.edu.br; jkoefender@unicruz.edu.br

${ }^{3}$ Universidade Federal de Santa Maria, Programa de Pós- graduação em Agronomia -Doutorado, Santa Maria, Rio Grande do Sul, Brasil. andre-schoffel@hotmail.com.

* Corresponding author:jkoefender@unicruz.edu.br
} 
Several factors are responsible for the success of culture techniques in-vitro. Plant growth regulators, mainly the ones belonging to the auxin and cytokinin groups (Caldas et al., 1998), are essential to develop some species based on tissue culture. Among the aforementioned growth regulators, auxins are associated with cell growth and stretching, as well as with callus formation (Nogueira et al., 2007). Cytokinins promote cytokinesis, induce organ formation and mobilize nutrients (Oliveira et al., 2007). Chaves et al. (2005) conducted a study with plant species $P$. peruviana $\mathrm{L}$, which belongs to the same genus investigated in the present research. The best shoot emission was recorded after 6-benzylaminopurine (BAP) addition to the culture medium.

Thus, the aim of present study was to evaluate plant responses to different growth regulator concentrations in $P$. angulata multiplication in vitro.

\section{MATERIALS AND METHODS}

Ripe Physalis angulata fruits were collected from plants grown in greenhouse. Fruits were pulped in the laboratory through manual maceration in water. Seeds used in this experiment were collected from a single plant that was kept together with other plants in the greenhouse; twenty fruits were harvested and seeds were randomized. A sieve was used to separate the seeds from the remaining plant residues and, later, they were washed in running water for five minutes. Next, they were left to dry at room temperature for seven days. Dry seeds were stored in glass vials sealed with foil and kept under refrigeration at $5{ }^{\circ} \mathrm{C}$, for seven days.

Seeds were immersed in $70 \%$ (v/v) ethanol for 30 seconds, for disinfestation purposes. Next, they were placed in $1 \%(\mathrm{v} / \mathrm{v})$ sodium hypochlorite P.A. $(\mathrm{NaOCl})$ solution added with two drops of Tween $20 \circledR$ for 10 minutes. Triple seed rinse with sterile distilled water was carried out in aseptic laminar flow chamber. Seeds were inoculated in $150 \mathrm{ml}$ culture flasks (ten seeds per flask) filled with $30 \mathrm{ml}$ of nutrient medium. The culture medium used in the current experiment was $1 / 2 \mathrm{MS}$; it comprised the Murashige \& Skoog's (1962) medium salt formulation reduced to half strength, as well as $30 \mathrm{~g} \mathrm{~L}^{-1}$ of sucrose, $8 \mathrm{~g} \mathrm{~L}^{-1}$ of agar and $100 \mathrm{mg} \mathrm{L}^{-1}$ of myo-inositol. Culture media $\mathrm{pH}$ was adjusted to 5.8 (before the autoclaving process) and media were sterilized at $121^{\circ} \mathrm{C}$, under $1.5 \mathrm{~atm}$ pressure, for 20 minutes. The flasks were kept in culture room at mean temperature $25 \pm 3{ }^{\circ} \mathrm{C}$ and under 16-hour photoperiod based on daylight fluorescent lamps at light intensity $30 \mathrm{imol} \mathrm{m} \mathrm{m}^{-2} \mathrm{~s}^{-1}$. Explants were collected after 20 cultivation days to install the multiplication experiment.

Nodal segments ( $8 \mathrm{~mm}$ ) from 20-day-old seedlings were used as explants for in-vitro propagation purposes. The experiment followed a completely randomized design, with 18 treatments and five repetitions. It was based on the factorial arrangement $2 \times 5 \times 2$, wherein factor " $A$ " encompassed two cytokinin sources (6-benzylaminopurine - BAP- and kinetin KIN), whereas factor "B" comprised different cytokinin concentrations $(0,2.5,5.0,7.5$ and 10 $\left.\mathrm{mg} \mathrm{L}^{-1}\right)$. Factor " $\mathrm{C}$ " consisted in the presence $\left(0.05 \mathrm{mg} \mathrm{L}^{-1}\right)$ or absence of 2,4-dichlorophenoxyacetic acid (2.4-D). The experimental unit was defined as a $250 \mathrm{ml}$ glass bottle containing $30 \mathrm{ml}$ of nutrient medium and two explants. The nutrient medium used in the current experiment was MS (at normal salt concentrations), added with agar, sucrose and myo-inositol at the same concentrations adopted for seed germination. Cultivation conditions were the same ones used for seed germination.

Mean number of buds, shoot length $(\mathrm{cm})$, number of internodes, incidence of calluses (\%) and roots (\%), fresh and dry explant biomass ( $\mathrm{g}$ ) were evaluated at the $45^{\text {th }}$ day of culture in vitro. Residue normality was assessed based on Bartlett test, whereas homoscedasticity was evaluated based on Komogorov-Smirnov test. Data were transformed by the $\sqrt{\mathrm{x}}+0.5$ function and subjected to analysis of variance, whenever necessary. The incidence, or not, of interaction in factorial experiments was assessed in case of significant "F" value. Quantitative data were subjected to polynomial regression analysis, whereas qualitative data were subjected to multiple comparison analysis based on the Tukey's test, at $5 \%$ probability of error, in the SISVAR statistical software (Ferreira, 2000). The maximum technical efficiency of each (quantitative) variable was calculated based on the methodology described by Storck et al. (2000).

\section{RESULTS AND DISCUSSION}

There was no interaction between the tested factors, either for different phytoregulator concentrations or for variable 'number of shoots per explant'. However, there was difference in growth regulator type. BAP use recorded the largest number of shoots per explant (2.14); its performance was superior to that of KIN (Figure 1). These data corroborate Rodrigues et al. (2013), who conducted a study with plant species Physalis peruviana and found satisfactory results after culture medium supplementation with BAP. Vicente et al. (2009) and Dode et al. (2003) also found satisfactory results after BAP addition to Vernonia condensata culture in vitro and to Ocimum basilicum $\mathrm{L}$ culture, respectively.

Variables 'callus' and 'fresh biomass' recorded significant interaction between cytokinin concentrations (regardless of BAP or KIN use) and the presence, or absence, of 2.4-D auxin (Table 1). The highest callus formation rate was recorded after 2.4-D addition to the culture medium without cytokinins. The lowest callus 
formation was observed after the highest cytokinin concentration tested in the current study was added to the culture medium. This outcome corroborates the hormone balance theory, according to which balanced auxin and cytokinin indices enable greater callus formation, whereas higher cytokinin concentrations enable bigger shoots. Auxins and cytokines are the core of a cell division and differentiation control mechanism that is essential to plants. Both growth regulators (auxins and cytokines) play a key role in cell division and bud formation processes (Schaller et al., 2015). However, it is worth mentioning that the lowest callus formation rate was observed when growth regulators were not added to the nutrient medium. Likewise, the highest biomass rate was observed in the absence of growth regulators.

Callus formation in the current study was undesirable, since it could lead to somaclonal variation; however, this outcome points towards the possibility of conducting future studies focused on indirect organogenesis or on the production of active principles in-vitro, in which calli play a key role. According to Dias et al. (2016), many studies focused on the production of phenolic compounds invitro were based on callus production.

Based on statistical analysis, there was interaction between different cytokinin types evaluated in the current study and their respective concentrations (Figure 2). KIN use recorded linear callus emission behavior (Figure 2A), since callus formation increased as the growth regulator concentrations increased. On the other hand, BAP use recorded quadratic behavior; the best callus formation result was observed after $10 \mathrm{mg} \mathrm{L}^{-1} \mathrm{BAP}$ use, if one takes into consideration that absence of callus was priority in the current study. This result was expected, since complete BAP absence in the presence of 2.4-D favors callogenesis, as well as its addition in equilibrium with the tested auxin. However, morphogenic routes linked to shoot formation reduce callus incidence in explants, when BAP concentrations become higher than auxin concentrations. Root formation also recorded interaction between growth regulator concentrations and different cytokinin types tested in the current study (Figure 2B). Both BAP and KIN were adjusted to quadratic pattern; the highest BAP and

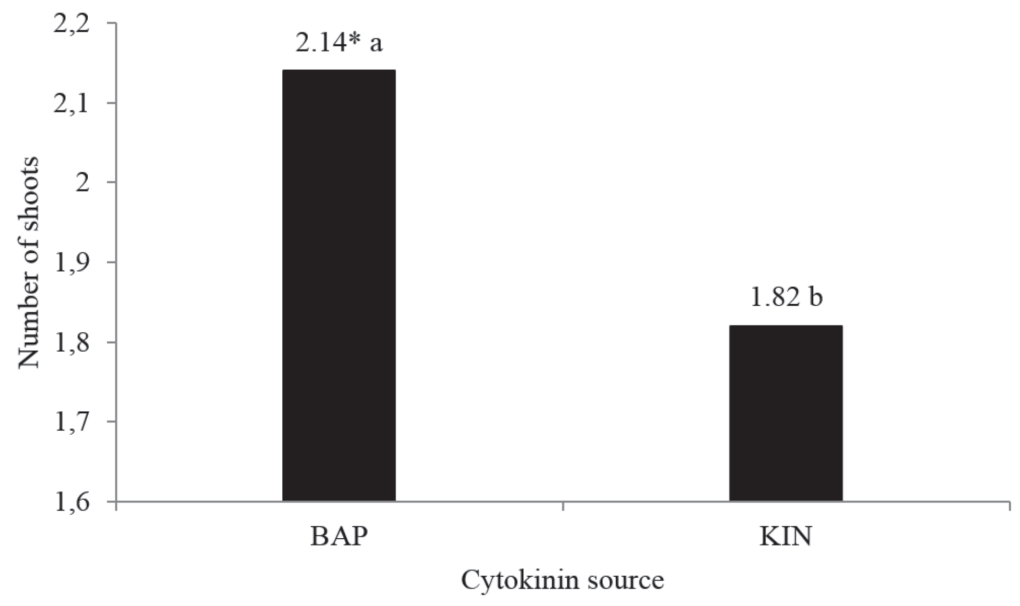

*Means followed by the same letter did not differ from each other in the Tukey's test, $\mathrm{p}<0.05$.

Figure 1: Number of shoots per explant after 6-benzylaminopurine (BAP) and kinetin (KIN) use.

Table 1: Effect of different cytokinin concentrations on Physalis angulata L. development in vitro, based on the presence and absence of 2.4-D in callus formation $(\%)$ and fresh biomass $(\mathrm{g})$

\begin{tabular}{|c|c|c|c|c|}
\hline \multirow[t]{2}{*}{ Concentration (mg L-1) } & \multicolumn{2}{|c|}{ Callus formation (\%) } & \multicolumn{2}{|c|}{ Fresh Biomass (g) } \\
\hline & Presence of 2.4-D & Absence of 2.4-D & Presence of 2.4-D & Absence of 2.4-D \\
\hline 0 & $100 \mathrm{~b} \mathrm{~B} *$ & 20 a A & $4.03 \mathrm{a} \mathrm{B}$ & $5.03 \mathrm{a} \mathrm{A}$ \\
\hline 2.5 & $80 \mathrm{ab} A$ & $80 \mathrm{~b} \mathrm{~A}$ & $2.58 \mathrm{ab} \mathrm{A}$ & $2.81 \mathrm{ab} A$ \\
\hline 5.0 & $90 \mathrm{ab} \mathrm{A}$ & $80 \mathrm{~b} \mathrm{~A}$ & $2.59 \mathrm{ab} A$ & $1.83 \mathrm{~b} \mathrm{~B}$ \\
\hline 7.5 & $100 \mathrm{~b} \mathrm{~A}$ & $70 \mathrm{~b} A$ & $2.54 \mathrm{ab} A$ & $2.64 \mathrm{~b} \mathrm{~A}$ \\
\hline 10.0 & 50 a A & $60 \mathrm{ab} A$ & $1.38 \mathrm{~b} \mathrm{~A}$ & $0.97 \mathrm{~b} \mathrm{~A}$ \\
\hline
\end{tabular}

*Means followed by the same lowercase letter in the column, and by the same uppercase letter on the line, did not differ from each other in the Tukey's test, $\mathrm{p}<0.05$.

Rev. Ceres, Viçosa, v. 66, n.6, p. 486-492, nov/dec, 2019 

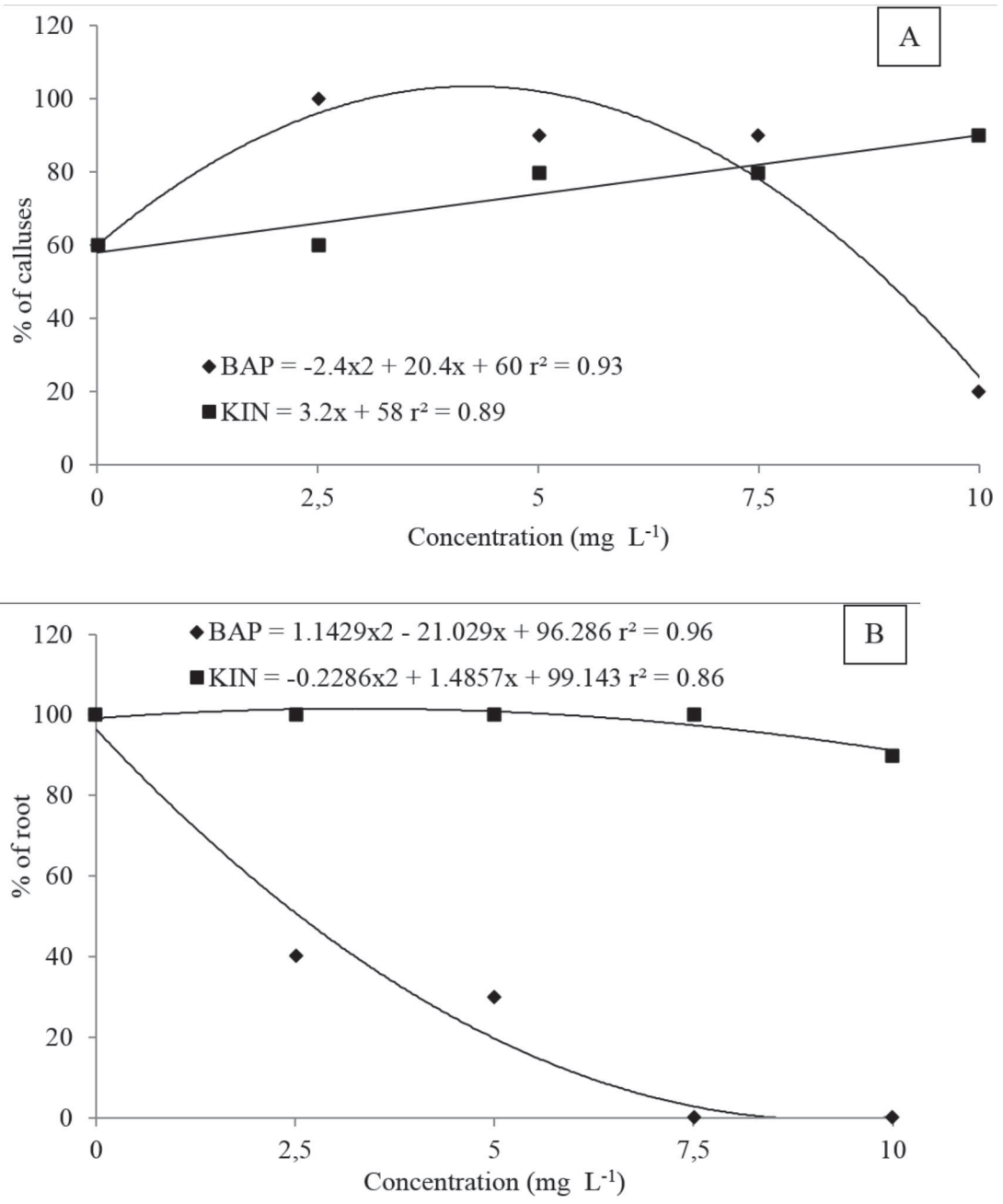

Figure 2: Effect of different BAP and KIN concentrations on the percentage of calluses (A) and roots (B) in Physalis angulata.

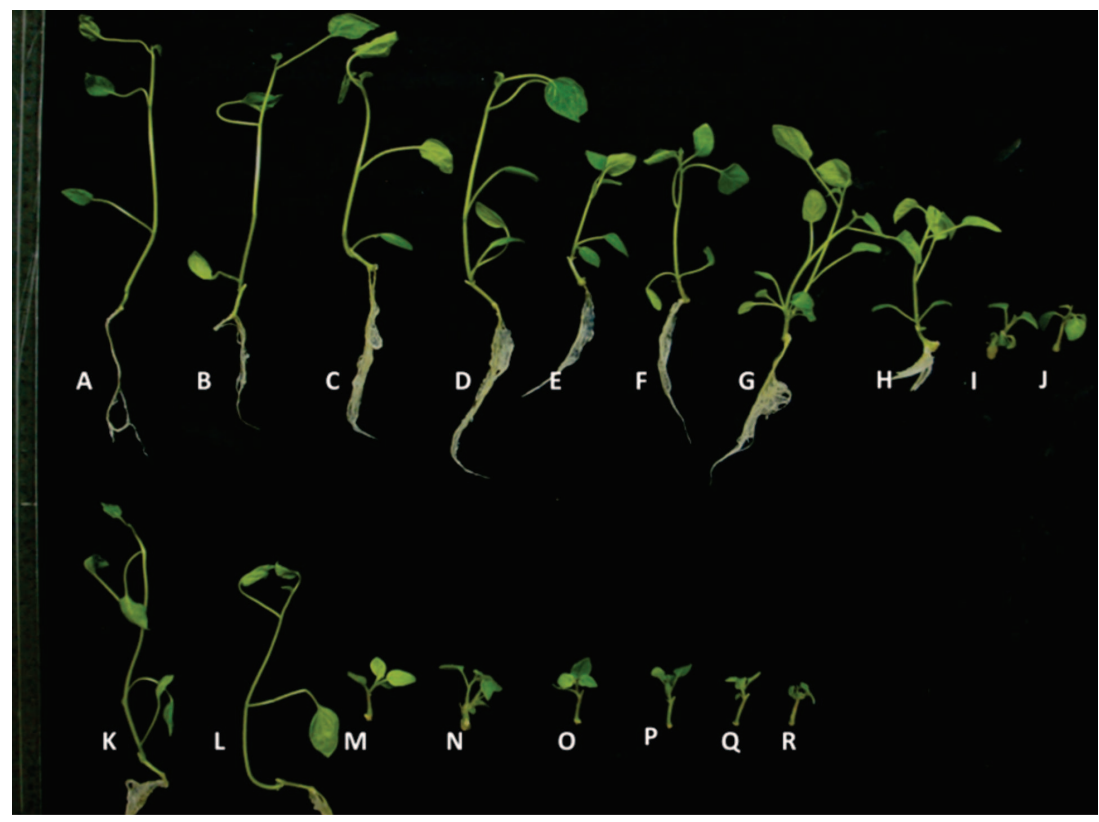

Figure 3: Physalis angulata $\mathrm{L}$. multiplication in vitro based on nodal segments. Letters represent the growth regulators $\left(\mathrm{mg} \mathrm{L}^{-1}\right)$. For 2.4-D added with KIN: A (0-0), B (0-2.5), C (0-5), D (0-7.5), E (0-10), F (0.5-0), G (0.5-2.5), H (0.5-5), I (0.5-7.5), and J (0.5-10). For 2.4-D added with BAP: K (0-2.5), L (0-5), M (0-7.5), N (0-10), O (0.5-2.5), P (0.5-5), Q (0.5-7.5) and R (0.5-10). 
KIN concentration $\left(10 \mathrm{mg} \mathrm{L}^{-1}\right)$ led to the lowest root formation. Ideally, new auxin-induced processes focused on forming adventitious roots should start after sprouting. According to Barrueto Cid (2000), different ways of balancing growth regulators change the morphogenic routes of plants grown in vitro; consequently, changes in phytoregulator concentrations play a key role at different micropropagation stages. Based on Silva et al. (2003), callus induction is caused by tissue competence and/or chemical induction, and genotypes can respond to both phytoregulator classes - cytokinin and auxin - and to their different combinations.

Figure 3 shows different visual results observed in plant development. Results referring to the lowest overall plant development are the ones representing the highest growth regulator concentrations. However, little difference was observed between growth regulators used at this first stage; thus, based on the principles of material handling, it is possible inferring, that auxins and cytokinins should not be added to the nutrient medium. On the other hand, additional studies focused on optimizing $P$. angulata multiplication in vitro should be conducted and, in this case, results would allow inferring that auxin 2.4-D should not be added to the nutrient medium and that higher cytokinin BAP level should not be evaluated.

Variable 'shoot length' (Figure 4B) recorded significant interaction between cytokinin types and tested concentrations. The longest sprout length $(7.5 \mathrm{~cm})$ was recorded after $7.5 \mathrm{mg} \mathrm{L}^{-1}$ of KIN was added to the culture medium. Higher BAP concentrations did not enable satisfactory results, since shoot length per explant decreased as BAP concentrations in the culture medium increased.
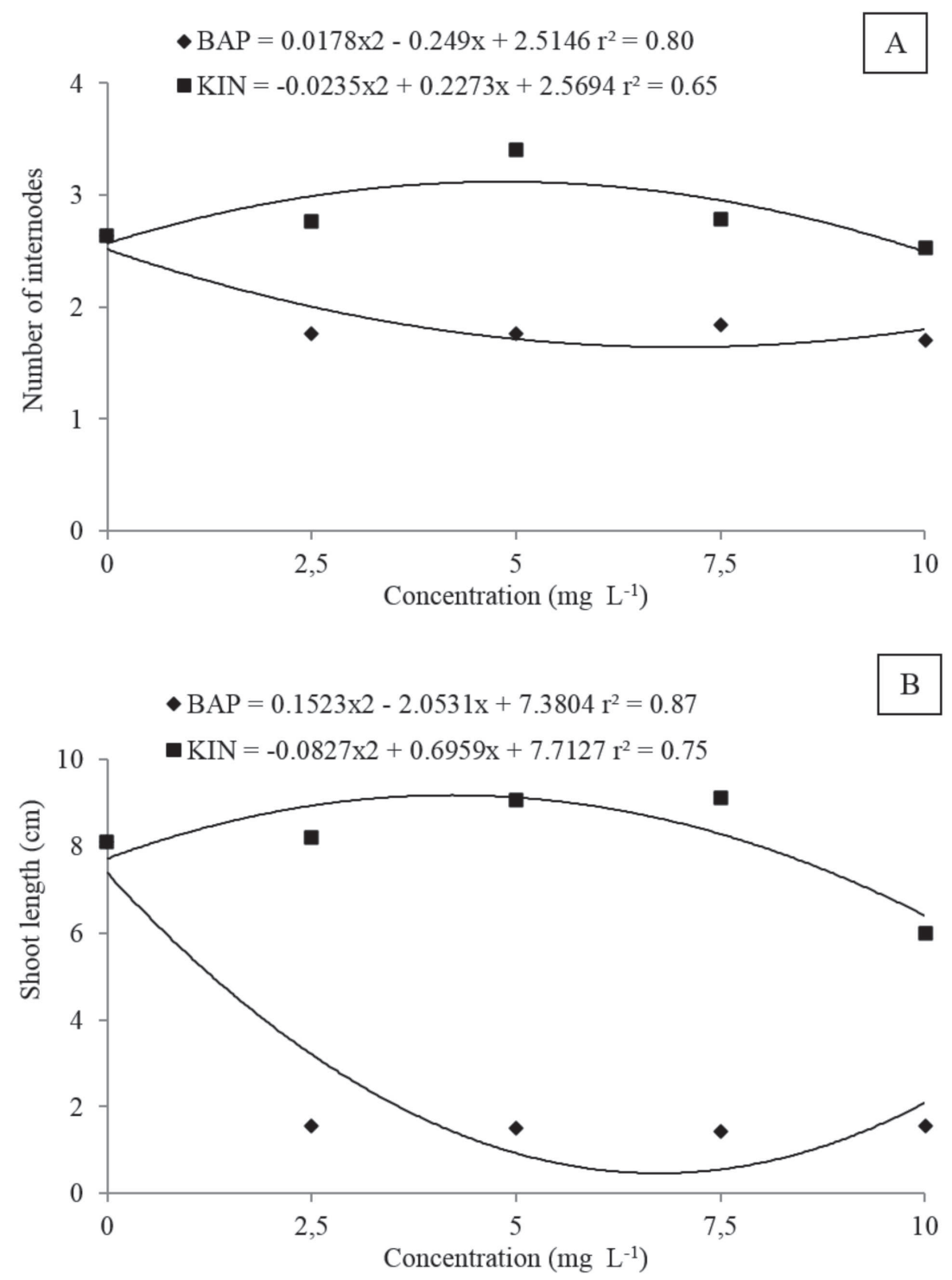

Figure 4: Effect of different BAP and KIN concentrations on the number of internodes (A) and shoot length (B) in Physalis angulata $\mathrm{L}$. 
Rodrigues et al. (2013) observed the same BAP effect on $P$. peruviana shoots grown in $50 \%$ of MS medium supplemented with $1.3 \mathrm{mg} \mathrm{L}^{-1}$ of BAP. The highest mean shoot length was recorded in the absence of cytokinin; this outcome may be associated with cytokinin's ability to break apical dominance and to favor the emission of new shoots. The aforementioned study is corroborated by Flores et al. (2009) who conducted a study with Pfaffia glomerata (Spreng.) Pedersen and found that the length of most shoots was lower than the one recorded for material cultivated in the absence of BAP. According to Chaves et al. (2005), P. peruviana buds subjected to different BAP concentrations reached maximum length $(7.3 \mathrm{~cm})$ in the absence of the regulator, whereas its minimum length (6.06 $\mathrm{cm}$ ) was recorded at BAP concentration of $0.3 \mathrm{mg} \mathrm{L}^{-1}$.

Variable 'number of internodes' (Figure 4A) was more responsive to $\mathrm{KIN}$ than to $\mathrm{BAP}$, since more than 3.0 internodes were observed at KIN concentration $5.0 \mathrm{mg} \mathrm{L}^{-1}$.
Higher BAP concentrations led to internode shortening, a fact that can affect the internode elongation and become a limiting factor in the rooting stage. However, the excessive use of this regulator leads to toxic effects, which are mainly characterized by lack of crop stretching, reduced leaf size, internode shortening, excessive stem thickening and generalized vitrification. These effects led to serious issues in the rooting stage (Chaves et al., 2005).

Based on the results, it is possible inferring that higher KIN concentrations - i.e., $7.5 \mathrm{mg} \mathrm{L}^{-1}$ and $5.0 \mathrm{mg} \mathrm{L}^{-1}$ - are efficient in increasing shoot length and the number of internodes, respectively. On the other hand, these concentrations can affect elongation and the number of shoots in the explant. However, it is important emphasizing that when the goal is to optimize multiplication, it is normal to have a reduced number of internodes and shorter shoot length. It happens because metabolic routes must be activated to enable
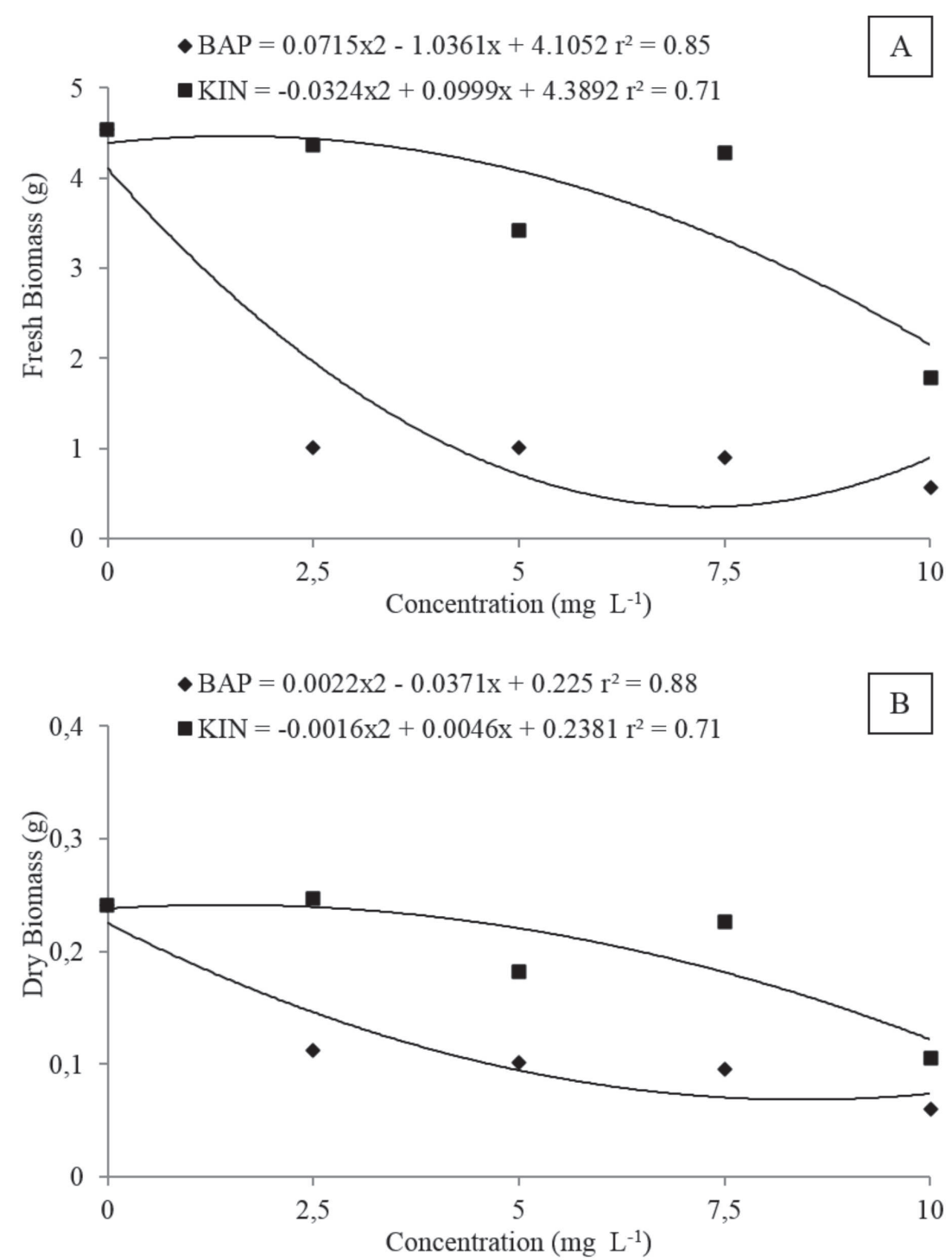

Figure 5: Effect of different BAP and KIN (kinetin) concentrations on Physalis angulata L fresh (A) and dry biomass (B). 
multiplication and for the stretching and rooting stages to take place (Grattapaglia \& Machado, 1998).

There was significant interaction between BAP and KIN concentrations in variable 'fresh and dry biomass' (Figure 5A e 5B). Cytokinin concentrations had quadratic effect on explant biomass. Higher BAP and KIN concentrations led to reduced biomass; $10 \mathrm{mg} \mathrm{L}^{-1}$ was the most damaging concentration. The study by Rodrigues et al. (2013) corroborate this outcome, since they found the best $P$. peruviana fresh mass result in the absence of BAP.

\section{CONCLUSION}

It is recommended using MS medium without growth regulator addition for $P$. angulata culture in vitro. Based on the herein evaluated conditions, it is possible optimizing plant multiplication in vitro by using 6-benzylaminopurine, which is more efficient than kinetin. However, further studies should be carried out based on higher concentrations.

\section{ACKNOWLEDGEMENT, FINANCIAL SUPPORT AND FULL DISCLOSURE}

The authors are grateful to Universidade de Cruz AltaUNICRUZ for funding the research. The authors declare no conflict of interest in the current study.

\section{REFERENCES}

Barrueto Cid LP (2000) Citocininas. In: Barrueto Cide LP (Ed.) Introdução aos hormônios vegetais. Brasília, Embrapa. p.889909.

Caldas LS, Haridasan P \& Ferreira ME (1998) Meios nutritivos. In: Torres AC, Caldas LS \& Buso JÁ (Eds.) Cultura de tecidos e transformação genética de plantas. Brasília, Embrapa-CNPH. p. $87-132$.

Chaves AC, Schuch MW \& ERIG AC (2005) Estabelecimento e multiplicação in vitro de Physalis peruviana L. Ciência e Agrotecnologia, 29:1281-1287.

Dias MI, Souza MJ, Alves RC \& Ferreira ICFR (2016) Exploring the plant tissue culture to improve the production of phenolic compounds: a review. Industrial crops and products, 28:09-22.

Dode LB, Bobrowski VL, Braga EJB, Seixas FM \& Schuch MW (2003) In vitro propagation of Ocimum basilicum L. (Lamiaceae). Acta Scientiarum Biological Sciences, 25:435437.

Ferreira DF (2000) Análises estatísticas por meio do Sisvar para Windows versão 4.0. In: Reunião Anual da Região Brasileira da Sociedade internacional de Biometria, São Carlos. Anais, Universidade Federal de São Carlos. p. 255-258.

Flores R, Nicoloso FT, Maldaner J \& Garlet TMB (2009) Benzilaminopurina (BAP) e thidiazuron (TDZ) na propagação in vitro de Pfaffia glomerata (Spreng.) Pedersen. Revista Brasileira de plantas medicinais, 11:292-299.

Grattapaglia D \& Machado MA (1998) Micropropagação. In: Torres AC, Caldas LS \& Buso JA (Eds.) Cultura de tecidos e transformação genética de plantas. Brasília, Embrapa SPI; Embrapa CNPH. p.533 568.
Guo L, Xue F, Guo J \& Na R (2014) Plant tissue culture: a recent progress and potential applications. Agricultural Science \& Technology, 15:2088-2099.

Koca A \& Aasim M (2015) Establishment of eficiente micropropagation system in bishop's weed (Trachyspermum ammi L.) usind seed as explant. Journal of Animal \& Plant Sciences, 25:478-484.

Murashige T \& Skoog F (1962) A revised medium for rapid growth and bio assays with tobacco tissue cultures. Physiologia Plantarum, 15:473-497.

Nogueira RC, Paiva R, Oliveira LM, Soares GA, Soares FP, Castro AHF \& Paiva PDO (2007) Indução de calos em explantes foliares de Murici-pequeno (Byrsonima intermedia A. Juss.). Ciência e Agrotecnologia, 31:366-370.

Oliveira LM, Paiva R, Santana JRF, Nogueira RC, Soares FP \& Silva LC (2007) Efeito de citocininas na senescência e abscisão foliar durante o cultivo in vitro de Annona glabra L. Revista Brasileira de Fruticultura, 29:25-30.

Puente LA, Pinto-Muñoz CA, Castro ES \& Cortés M (2011) Physalis peruviana Linnaeus, the multiple properties of a highly functional fruit: a review. Food Research International, 44:17331740 .

Rodrigues FA (2013) Diferentes concentrações de sais do meio MS e BAP na multiplicação in vitro de Physalis peruviana L. Bioscience Journal, 29:77-82.

Schaller GE, Bishop A \& Kieber JJ (2015) The Yin-Yang of homones: cytokinin and auxin interactions in plant development. The Plant Cell, 27:44-63.

Silva FG, Pinto JEBP, Sales LF, Divino SP \& Bertolucci SKV (2003) Efeito da concentração de sais e fitorreguladores na indução de calos em carqueja. Ciência e Agrotecnologia, 27:541547.

Soares ELC, Vendruscolo GS, Vignoli-Silva M, Thode VA, Silva JG \& Mentz LA (2009) O gênero Physalis L. (Solanaceae) no Rio Grande do Sul, Brasil. Pesquisas, Botânica, 60:323-340.

Storck L, Garcia DC \& Lopes SJ (2000) Experimentação vegetal. Santa Maria, UFSM. 198p.

Vicente MAA, Almeida WAB \& Carvalho ZS (2009) Multiplicação in vitro e aclimatação de Vernonia condensata Baker. Revista Brasileira de Plantas Medicinais, 11:176-183. 